\title{
A PRAÇA PÚBLICA E A LITURGIA POLÍTICA
}

\author{
I ARA LIs SchiaVInatto*
}

RESUMO: Tratase das formas de celebração do 7 de Setembro e a construção de seu significado simbólico.

Palavraschave Identidade Celebração. Cultura política.

THE PUBLIC PLACE AND THE POLITICAL LITURGY

ABSTRACT: This article analyses the meanings of Independence Day in Brazil.

Key words Identity. Celebration. Political culture

* Departamento de Multimeios da Universidade Estadual de Campinas (UnICAmp). Email: iaralis@uol.com.br 
quadro de Pedro Américo sobre a independência do Brasil, Independência ou Morte, fixou uma imagem do gesto, do herói, do local e da necessidade de uma ação decisiva e militarizada que declarasse a independência $O$ quadro tornou-se peçarchave do Museu Paulista e reitera, no presente, o mesmo gesto fundador. Feito em 1888 e apresentado, primeiramente, para majestades inglesas, italianas e bra sileiras em Florença, o quadro definiu uma cena primeira e única do fato histórico que funda a nação e foi elaborado por meio de uma série de referências da pintura histórica eacadêmica oitocentista. A força desse quadro, sua repercussão, contínua divulgação e repetida publicação aca baram por erigi-lo na própria cena da independência ou na imagem do próprio fato. Recentemente, na minissérie de TV O Quinto dos Infernos com o enredo baseado mais numa versão literária, fabulosa, em tom camavalesco e caricatural, quando a narrativa exige que se mostre o to da independência, evocase a mesma formatação gerd da cena de Pedro Américo, homens a cavalo, no cume da colina espada ao alto a fim de comunicar ao espectador que ali $\mathrm{D}$. Pedro estaria inventando um pás, como dizja o personagem Chalaça A forte presença dessa imagem na memória nacional colocou numa espécie de limbo, num lugar opaco, outras cenas e representações, marcadamente públicas, em torno do processo de autonomização do Brasil.

Durante o século XIX, apareceram várias figurações do aconte cimento-independência, muitas calcadas em testemunhos de época, dos escritos de Mello Moraes ou na descrição de Varnhagen, por exemplo. Em litografias, litogramuras, e na própria produção pictórica da Academia de Belas-Artes existiam outros modos de representar esse evento. Assim, a imagem oscilava ora, D. Pedro era cercado de militares e civis, uns e outros dispersos na cena; ora o príncipe não estava a cavalo, ora a cena não se centrava no herói, ora não havia um alto da colina ora de segurava o livro da constituição. Dessa maneira, as versões desse ato osálavam, como no quadro Prodamação da Independênda, de François-René M oreaux, com muitos civis, vários militares a cavalo, cada qual para um lado, dando vivas. Em seu cavalo branco, D. Pedro, no primeiro plano, saúda com o chapéu a boa nova e dois meninos correm vibrantes no primeiríssimo plano.

Entre as décadas de 1850-60, criou-se uma interpretação acerca da maneira pela qual teria se passado o ato da independência no I piranga, baseada no depoimento de D. Pedro I de 1823, em testemunhos de época e estudos históricos. Vamhagen,2 por exemplo, afirmava, em 1854, a tríade grito, I piranga, figura de D. Pedro que acabou por 
conformar um cenário, uma ação, um protagonista para o đo que inaugura a nação. Aos poucos e a partir de vários escritos, o ato ganhava uma imagem. Destacavase que em 7 de setembro nascera a nação. Uma versão importante foi elaborada por Araújo Porto-alegre, historiador da arte, pintor, membro do Instituto Histórico e Geográfico Brasileiro, diretor da Academia de Belas-Artes, autor de artigos em jornais da época Num artigo publicado em $\mathrm{O}$ Guanabara, ${ }^{3}$ Porto-alegre fez uma descrição quase literária - que se queria literal - do ato da independência. Porto-alegre recomendou que a figura de $\mathrm{D}$. Pedro estaria em pose eqüestre Primeiro, porque o cavaleiro e o cavalo compartilham as fadigas da guerra e as górias do combate Em especial, identificava o momento histórico que a estátua representaria: o ato da independência, o momento supremo deste herá. Ele chegou a narrar esse momento, sucintamente O herá, caminhando pda etrada de São Paulo, pára o seu cavalo no regato do I piranga, e prodama a independência do Brasil. Ele também presidiu a Comissão que em 1860 avdiou e escolheu o projeto da estátua pública a representar D. Pedro I em seu gesto maior. Dessa es colha, resultou a estátua inaugurada em 1862, com a presença de D. Pedro II, pompa e circunstância, na Praça da Constituição - hoje Praça Tiradentes - no Rio de Janeiro. Aí, num gesto expansivo e eloqüente, D. Pedro, no cume da colina e com o livro da constituição ao alto, de clara a independência com o grito.

Conhecer tais representações públicas e seus usos faz pensar acerca de uma noção de cidadania historicamente construída por meio de uma série de śmbolos que (re)significam o passado. Procurase aqui, as sinalar a existêndia de outras liturgias políticas, suas cenas públicas e significados, em tomo da fundação do Brasil. Muitas desaparecidas de nos sa memória social. Para tanto, esboçam-se brevemente duas celebrações. Primeiro, apresentam-se, grosso modo, as formas celebrativas da instalação do Brasil como corpo político autônomo na década de 1820 e, depois, remetese a 1972, quando novamente a independência serve de tema a uma imensa comemoração da nação e o uso que se fez da praça pública

Nas celebrações de 1822-26 marcase a autoridade de D. Pedro I, herói da independência por excelência, seu chefe político e militar, Defensor Perpétuo da Nação, Anjo do Brasil, Gênio do Brasil, títulos ganhos por unir o território e afastar-se do risco efeivo de o pás ser fra turado da mesma forma que a América Hispânica. $E$ ainda, em virtude de sua atuação, em meio aos debates acalorados e movimentos liberais constitucionalistas em Portugal e no Brasil, na montagem e no estabelecimento de uma monarquia constitucional com a qual se 
comprometeu e como negociou com vários protagonistas sociais e políticos seu modo de governar. Afirmava-se, por meio de sua persona, uma noção de pátria que remetia ao amor à localidade, onde se nas ceu, defendeu fazendas, vidas, majestade, dignidade, e este vínculo com a localidade foi celebrado em toda parte com signos assemelhados, similares ou os mesmos, de modo que ressoava em toda a comunidade e se forçava uma relação identitária que iria para além da localidade, modelava-se com a pátria - uma noção difusa de todo, marcada por intensas acepções de identidades locais (baianos, mineiros, pernambucanos) que (man)tinham uma experiência partilhada ${ }^{4} A$ noção de pátria no início do século XIX passou a significar mais que o local de nascimento, passava a significar também a escolha política de aderir à causa do Brasil. Maria de Lourdes Viana Lyra assinalou que com a Re volução Francesa o sentimento nadional - antes ligado apenas ao ré eà religãa - adquiriu um sentido de um novo "corpo mísico", que era a nacionalidade $\mathrm{O}$ movimento révindicador de um novo contrato social levara à ruptura revolucionária com o passado arcaico e os homens, libertos do poder opressor do Ancien Régime, foram chamados, como cidadãos a se constituírem em naçãa ${ }^{5}$ Aí, nação e pátria assemel haram-se

Já em 1972, uma releitura da independência dava ao governo militar uma espécie de miragem de si refletida no passado, bem como explicitava para si e a qualquer um como gostaria de ser designado naquele momento, pois sua autoridade se espelharia em D. Pedro I, ao integrar o território nacional, defendendo-o do que considerava os adversários políticos internos e externos, ao pautar-se pela ideologia da Segurança Nacional.

Entre a cena pública e a praça de 1822-26 e 1972, há uma intensa e cortante diferença, embora numa e noutra a liturgia política te nha sido importante e instrumentalizada Não se trata de recuperar uma em detrimento de outra ou de escolher a mais verdadeira, a mais importante Longe disso, a intenção é indicar apenas que a praça pública e o to de celebração político são chaves para esboçar de que maneira se traz o passado à tona, buscando, por vezes, revivêlo. Ademais, repetir não significa colocar de novo o mesmo, antes, na repetição, vêse a dife rença No limite, talvez seja plauśvel pensar numa história da praça púr blica entre nós, do lugar público, e estudála talvez seja também uma maneira de desfazer-se da idéa de que "brasileiro é assim mesmo" ou "desse jeitinho". Além disso, no início do século XIX pela primeira vez emergia a noção de que o didadão - ou o súdito-didadão, como muitas vezes se diża - participa da pátria/nação. 
No início da década de 1820, a praça pública em torno do príncipe e futuro imperador foi agenciada de várias formas $\mathrm{N}$ la se deram muitos vivas e serviu de palco às allamações da Assembléa Constitucional Vintista, convocada em Lisboa, e, posteriormente, à adamação do imperador D. Pedro I. Essa adlamação designava por si a ruptura definitiva com Portugal. Contudo, havia discordâncias sobre a figura de D. Pedro e quem o investia de tal poder. Na Gazeta do Rio de Ja néro, D. Pedro libertava o Brasil da escravidão imposta pelas Cortes de Lisboa Já para J oão Soares Lisboa, redator do Corréo do Rio deJa nèro, ${ }^{6}$ o imperador resultava da soberania popular. Havia divergências e disputas políticas acirradas quanto ao significado dessas celebra ções, que muito se revestiam com os śmbolos do Antigo Regime para explicitar a nova ordem política

Também, na praça, houve uma série de enfrentamentos entre negros, brancos, escravos, libertos, fugidos e aquilombados, proprie tários, comandantes militares, mulatos, índios, pobres livres, cada qual a seu modo definindo questões e modos de adentrar no novo pacto político a ser estabelecido dentro da Família Luso-Brasileira e, na se qüência, no Império do Brasil. Nesse aspecto, é importante destacar o que João José Reis? chamou de Partido Nego, uma explícita reivindicação de cunho racial que se expressava nas assembléas, em gestos cotidianos, em revoltas, em petições e também na praça pública Dis cutiu-se a noção de pacto do liberalismo constitucional em várias es feras: entre ministros, nas assembléas, nas eleç̧ões, nas câmaras, nos cortejos públicos, em casa e nos diversos espaços de sociabilidade: tavernas, boticas, oficinas, largos, no novo campo da opinião pública caracterizada pelos jornais e pela implantação da imprensa no Brasil.

Num tipo de documentação freqüente para a questão da autonomização do Brasil, em que as câmaras expressam sua adesão à figura de D. Pedro, a câmara de Baependi, em Minas, explicava a origem do contrato social numa correspondência endereçada a D. Pedro justificando sua adesão à causa do Brasil:

Quando os primeiros homens se uniram em Sociedade Civil, não foi senão para poderem gozar pacíficos da tranqüilidade, e sossego, que não encontravam nos bosques; por esta razão el egeram desde logo um dentresi, que os governasse, e defendesse, em cujas mãos depositaram uma partícula de sua li berdade natural para que a outra lhes ficasse salva, e a coberto ou da mal ignidade, ou da força dos mai s destemi- 
dos, e poderosos. I sto era necessário: despiram-se de al guns Direitos para poderem conservar os outros.

\section{Em seguida, a correspondência ressaltava:}

(...) osquequeriam mostrar commaior afero, eadesão àC ausa B rasileira, e que, para o fazerem publicamente, queriam fazer umaMissa soleneao Espírito Santo, um discurso análogo àscircunstândias, umTeDeumLaudamus e alguns espetácul os públicos, que coubessemna urgêndia do tempo.

Numa via de mão-dupla, Clemente Pereira, em meio a várias divergências políticas, ressaltava em seu discurso, em nome da Câma ra do Senado do Rio de Janeiro e dirigido a D. Pedro, no dia de sua adamação no Campo de Santana:

(...) era vontade universal do povo desta Província edetodas as outras, como se conhecia expressamente dos avisos de muitas Câmaras de (...) sustentar a I ndependência do Brasil, que o Mesmo Senhor, conformando-secoma opinião dominante, tinhajá dedarado (...) I mperador Cons titucional do Brasil eseu Defensor Perpétuo. ${ }^{8}$

Emergia a questão candente quanto à forma de aceitar, da parte de cada um, este viver em sociedade e seu novo modo de governar assentado na monarquia constitucional. Esses espaços públicos se inflamaram também com os tantos jornais, panfletos, catecismos, repre sentações, livrinhos, hinos, quadrinhas, discursos, redamações, enfim uma ordem discursiva na qual circulavam e discutiam os novos temas em voga e, nesta dinâmica, as relações entre Brasil e Portugal. Muitos escritos eram lidos e comentados, até decorados, nas tipografias, livra rias, ruas, circulando e difundindo-se numa cultura bastante vincada pela oralidade Tratavase de uma ordem discursiva marcada pela dis puta política, pelas discordâncias, por polêmicas acaloradas e diversos projetos e vontades que rivalizavam entre si buscando a simpatia do leitor/ouvinte. Muitas vezes, os textos revestiam-se com formas discursivas bastante conhecidas, próprias do passado pelo caráter sacro, filhas do Antigo Regime, que, agora, anunciavam um novo ideário político. Como esta Ave M aria Constitucional:

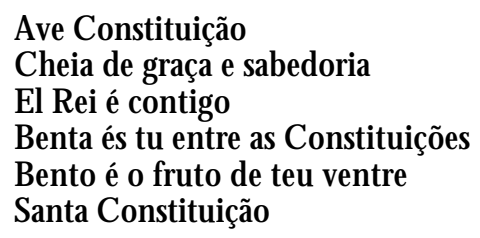


Mãedos Portugueses

Vigia por nós agora

E nahora denossamortecivil ou política

Amém

A cena pública foi sendo, num jogo de conjunturas e alianças, (re)direcionada com o avd e apoio de boa parte das dites para a figura do novo governante, celebrando, de uma só vez, a instauração de um governo monárquico constituciona, o imperador e seu império: o próprio Brasil independente Configuravase, num mesmo torvelinho, a fundação do Brasil, como corpo político autônomo, seu novo governante, a ruptura com Portugal, acusado de (des)mandos coloniais, de jugo no passado, de aprisionar as capacidades produtivas, comerciais e políticas do Brasil, como se vê nos Manifestos de agosto de $1822 .{ }^{9}$

No processo de autonomização do Brasil, sobressaem-se algumas celebrações, como notavam os jornais da época (Gazela do Rio de)anèro, O Espdho, Regulador Brasileiro, Corréo do Rio deJaneiro e outros) e alguns estudos históricos posteriores de Oliveira Lima Otávio Tarquínio, sabendo-se que celebrar também significava, segundo o Vocabulário de Bluteau e o Dicionário do Moraes, ${ }^{10}$ celebrar matrimônio, solenizar, cele brar pacto, com grande lavar. Assim, convém elencar:

- As viagens a Minas e São Paulo entre abril e setembro de 1822, com várias entradas para saudar D. Pedro. A entrada era uma cerimônia real do Antigo Regime, com forte caráter sacro, na qual o governante é recebido num cortejo solene, com ruas enfeitadas, missa, sob pálio, com Te Deum missa, desfile militar, arcos do triunfo, vivas, hinos, poesia, ruas atapetadas, as pessoas endomingadas, em gestos ditados pela etiqueta, sendo que cada um assumia um lugar no corpo social bastante hierárquico da vila e da sociedade, dando-se a ver e vendo os outros e, nesta medida, reconhecia a si e ao outro na ordem social. A entrada também selava o pacto de governo entre o príncipe e sua gente, ao demonstrar a adesão coletiva e de cada um e reforçar os elos de fidelidade, obediência, de todos ao governante que deveria responder pela harmonia deste corpo.

- A adamação no Rio de Janeiro em 12 de outubro de 1822, primeira cerimônia ávica do Império do Brasil, e sua repetição em inúmeras vilas do Brasil, até 1826. Era acompanhada, na maior parte das vezes, da farta distribuição do retrato real por várias vilas do pás, então recepcionado nos moldes da entrada 
- A coroação de D. Pedro I em 10 de dezembro de 1822, realizada apenas no Rio de Janéro. Tratase de uma cerimônia que rompe com a liturgia real portuguesa porque, com D. Pedro I, nasce a coroação na realeza brasilera diferenciando-se da dinastia portuguesa e inspirando-se na coroação de N apoleão. Alguns jornais da época e parte da historiografia estabelece ram uma interpretação na qual a data teria sido estrategica mente escolhida, pois conseguiria advertir aos portugueses que o Brasil não desejava retornar ao mando português tanto quanto os portugueses desejavam permanecer independentes da Espanha, dado que o 10 de dezembro, até hoje data nacional portuguesa e feriado, recorda aos portugueses a conquista de sua autonomia ante a Espanha no século XVII.

Essas celebrações se enredavam a outras tantas que se tinha vivido de forma intensa desde a transladação da corte em 1808, quando se instaurou no Rio de Janeiro um tempo forte de ritos reais. Esse tempo festivo também estava profundamente marcado pelo calendário católico de dias religiosos, dedicados aos santos de devoção, e imbricava-se com as datas da rẹleza. Esse tempo forte de ritos ćivicos, entre 1808-1820, centrava-se muito na figura do governante real, nos natalícios de D. João (13 de maio) e D. Pedro (12 de outubro), no 7 de março, dia do desembarque da família rel no Rio de Janeiro. Enalteciase muito os vínculos entre sua majestade e a figura da América e do Índio chamado Brasil. A partir de 1820, a liturgia política privilegiava a monarquia constitucional, daí a recuperação insistente da independência de Portugal ante a Espanha, na abertura das Cortes Constitucionais, na adesão de D. Pedro à causa constitucional em 26 de fevereiro de 1821, na adlamação red, sublinhando a noção de pacto político - no caso, constitucional - que sedimenta e funda a vida coletiva.

Durante o período joanino, várias celebrações reiteravam a grandeza da monarquia portuguesa, enaltecendo as datas da funda ção da monarquia portuguesa, da perda de D. Sebastião, da restauração monárquica no século XVII. Festejadas publicamente serviam para congraçar os elos entre o governante e o governado, exigindo obediência e fiddlidade devidas a esse pai real (D. João) que governa em nome do Bem Comum, promove a prosperidade crescente do Brasil, exerce a justiça Neste sentido, destacase uma série de cerimônias entre 1808-20 principalmente no Rio de Janeiro, que funcionava com um calendário próprio, pois lá se comemorava a recep- 
ção da família real, embora não encontrasse correspondência em Lis boa Convém arrolar as cerimônias joaninas:

- A recepção da família rea. A cada ano festejavase o 7 de março, dia da chegada da família real, com missa, Te Deum luminárias, cortejos religiosos, militares e de civis, apresentações teatrais, salvas de canhão, bandas e músicas. 07 de março marcava o império luso-brasileiro e a presença do governante no Novo Mundo, evocando assiduamente as figuras da América e do Í ndio-Brasil que de joelhos, em versos, com gestos, as severam a gratidão e a obediência a D. João.

Ato contínuo, uma série de ocasiões festivas comemorava a re conquista de Portugal dos franceses, a expulsão do exército francês e, depois, a derrota de Napoleão. Nessas festividades, qualificavarse muitas vezes $\mathrm{D}$. João como a antítese de Napoleão, considerado em opúsculos, sermões, peças de teatro o Anticristo. Insistiarse em qua lificar Napoleão como a expressão do mal tal qual nesta Receita espe dal para fabricar Napoleões

Tomaum punho deterra corrompida

Umquintal dementira refinada

Um barril de impiedadealambicada

Deaudácia uma canada bemmedida

A cauda deum Pavão toda estendida

Com uma unha deTigreensangüentada

DeCorso o coração, ea refalsada

Cabeça deraposa envelhecida

Tudo isto bem cozido em lento fogo

Do exterior fagueiro, maigo ebrando

Atrevida ambição Ihelancerogo

Deixaquesevátudo incorporando

E assim mui presto espera; porquelogo

Sai um Napoleão dali voando.

Havia uma espécie de disputa entre esses governantes - D. J oão e Napoleão -, sendo que o modelo de D. João permitia a felicidade e a civilização no Brasil. De todo modo, sua figura real padecia nesse jogo de contrastes, pois expressava a dificuldade em bem governar e manter a unidade do império luso-brasileiro.

- Os casamentos reais de 1810 e 1817 que saudavam importantes alianças diplomáticas com Espanha e Áustria;

- As exéquias da rainha D. Maria I em 1816; 
- As celebracões promovidas pela monarquia ao derrotar Pernambuco insurgente, sendo que a sagração da bandeira republicana no Recife, na Semana Santa de 1817, marcara o nascimento de um novo tempo, um novo calendário, um novo governo e de seria guiado pelo sol e pelos ideais republicanos. Ao derrotar esse movimento, D. J oão exigiu sua adamação em Pernambuco a fim de explicitar e exibir seu mando, e um rito político - no caso, a aclamação real - vinha contrapor-se à liturgia republicana acontecida, derrotando-a e acusando-a de não honrar o passado heróico dos pernambucanos que expulsaram os holandeses em favor do ré português. Bem como se vibrava pela derrota, no mesmo ano, do movimento militar de Gomes Freire em Portugal, que ensaiava um novo sistema de governo. D. João e sua corte temiam que essas revoltas ultrapassassem o âmbito regional e se articulassem, fraturando o Império.

- A adamação de D. João VI em 1818. Sendo que entre o desembarque de $\mathrm{D}$. Leopoldina e a adamação há uma série de ocasiões festivas repiques de sino, salvas de canhão, missas, embaixadas oficiais. Na adamação de D. João VI, ocorrida com sua presença física no Rio de Janeiro e repetida em várias partes do Brasil com seu retrato ou não, o ré ocupava a cena pública e demonstrava a sua capacidade de manter a ordem e promover a unidade do Império, pois vencera Napoleão, os horrores revolucionários, e a re volução pernambucana e o movimento revolucionário de Gomes Freire em Portugal, que também desejara depor o ré. Nessa ada mação, (re)valorizourse o passado da monarquia portuguesa, seus heróis e feitos, sendo celebrada no dia das Chagas de Cristo, insistindo no caráter místico dessa monarquia

Com a irrupção do movimento constitucional vintista em Lis boa, a figura de D. João VI, central nas celebrações arroladas, passa a se amesquinhar, recolhese para o palácio, às missas e aos espaços domésticos. O Rio de Janeiro volta a viver um tempo forte de celebra ções em torno de D. Pedro, depois da partida de D. João. A festa de entrada e a aclamação, mais esta do que aquela e principalmente a ada mação realizada no Rio de Janeiro em 12 de outubro de 1822, expunham a face pública desse novo governo e explicitavam os vínculos contratuais entre governante e governado. Neste sentido, a figura da América paredia sair pelas mãos de D. Pedro I do seu estado de inocência elou da sua infância, marcava-se o vínculo quase amoroso entre eles, e reiterava-se a relação á constitucional estabelecida. 
O pacto liberal consagravase na Constituição li beral, santa ejusta, na effera de decisão do que se erigia no Estado do Brasil tanto quanto precisava tornar-se público nas celebrações, ritualizando a vida coletiva e inaugurando um novo tempo do pás ao designar o seu momento de origem. Esta liturgia real adentrava a vida e a memória de cada um e da sua vila, batalhão, câmara etc., porque muitos costuraram pálios e roupas, outros ergueram arcos do triunfo e atapetaram as ruas, tantos deram vivas, ou seja, com seus corpos e gestos participavam da cena pública Cabe mencionar que os arcos, os bailados, as luminárias, as músicas e muitos comes e bebes eram tradicionalmente ofereddos, custeados, feitos por determinados grupos sociais. ofícios, comerciantes, negociantes, instituições, que dessa maneira expressavam publicamente sua al egria eadesão ao governo. E, de mais a mais, como não contar para o filho ou comentar com o vizinho assunto tão rele vante como uma celebração desse porte? Também dessas formas a independência do Brasil foi adentrando a vida das pessoas que muito debateram e se valeram do direito de se manifestar nos debates cons titucionais, enviar representações, apresentar petições, fazer abaixo-as sinados e esbravejar, brigar e blasfemar contra portugueses e brasilejros em favor da manutenção da Família Luso-Brasileira, ou ainda o pegar em armas para defender o lema da Independênaia ou Morte

A perda e o esquecimento dessas celebrações no processo de autonomização do Brasil devem-se, em parte, à elaboração do ideário republicano de fins dos oitocentos e à invenção de uma outra tradição nacional e heróica bastante referida na Inconfidência Mineira e em Tiradentes. Em Revoluções Brasileiras de Gonzaga Duque, uma espécie de manual de história usado na formação escolar, publicado em fins do XIX nos conformes republicanos, bastante tributário da idéia de progresso, D. Pedro I assemelha-se a um rei absolutista, caracterizado pela tirania, pelos arroubos de desmandos pessoais e pelo temperamento passional. O esquecimento desta liturgia real, de uma monarquia constitucional, repõe em nosso campo de visibilidade noções de luta política e de cidadania que passaram pela praça pública, pela sua mobilização e por uma série de enfrentamentos, pelas formas simbólicas e por seus significados, distanciando-se de uma versão da história na qual o povo é apenas aquele que assiste ou a praça pública somente obedece ao já decidido. Antes, ela conferia significado à noção de pacto político e em si explicitava e inaugurava a própria fundação do pás e de sua história. 
Em 1972, em vez do retrato de D. Pedro circulou pelo Brasil o corpo de D. Pedro I transladado de Lisboa para o pás e, depois, definitivamente depositado com grande pompa e aparato militar no Museu Paulista, em São Paulo.

O corpo saiu de Portugal, vindo de navio para cá Insistiase, no rádio, nos jornais e cinejornais, que o corpo recebia um trata mento respeitoso durante seu translado. Um paquete traziaro sem divertimentos, com bingos regrados, chás e passeios no convés. Nada além. As rádios portuguesas noticiavam que o então presidente português todo dia reverenciava, no trajeto marítimo, o féretro. Esse gesto revelava a solenidade implícita no translado e no retorno de um herói à pátria onde foi sagrado imperador. No entanto, seu coração, doado à cidade do Porto pelo próprio D. Pedro em seu leito de morte, em 1835, permanece lá, considerado uma relíquia cívica e guardada na Real Capela de N ossa Senhora da Lapa e das Confissões, poucas vezes sendo exibido e visto. Assim, D. Pedro continua a centrar em si, no seu corpo morto, significados políticos em Portugal e no Brasil de forte conotação nacional. Aliás, em 1972, enfatizavase muito esta amizade entre Brasil e Portugal, seus laços de fraternidade

O retrato de $D$. Pedro e o quadro de Pedro Américo foram, no início da década de 1970, assiduamente reproduzidos e divulga dos nos jornais e em revistas de maior circulação, nas capas dos cadernos escolares, nos livros didáticos de Estudos Sociais e Educação Moral e Cívica, em cartazes e calendários, na nota de dinheiro mais corrente de um cruzeiro e, por último, sua figura foi encarnada pelo galã de telenovelas Tarcísio Meira, no filme Independêndia ou Morte, de Carlos Coimbra

De várias maneiras, o imperador, tornado herói eminentemente militar, voltava ao Brasil e circulava pelo pás em mídias diversas e através da peregrinação que o féretro fez pelo Brasil de norte a sul, entre 22 de abril até o 7 de setembro. Seus restos mortais foram exibidos em várias partes do país, de norte a sul, recobrindo um território diferente daquele que se designava Brasil em 1822, pois, em 1972, por exemplo, foi ao Acre, que não pertencia ao Brasil.

O corpo percorreu o pás dentro de um calendário ć́vico, porque chegou na data em que se comemora o descobrimento do Brasil pelos portugueses e encerrou seu périplo finalmente quando o fére 
tro/corpo morto/herói teriam (re)encontrado seu ato de maior grande za e seu lugar original: a colina do I piranga consagrada, definitiva mente, num museu nacional. Neste sentido, a data da independência, 7 de setembro, ganhou maior intensidade, dignidade, aparato e significado do que o 22 de abril, outro feriado nacional. Mas não havia necessariamente uma unanimidade, pois como declarou um PM à Veja, na solene chegada do corpo com a presença dos presidentes de Brasil e Portugal, em abril de 1972: Encontro de presidentes não dá ibope Se não estivesse aqui de serviço, palavra que estava com minha eteira lá na praia.

Espraiava-se e repetia-se nas mídias audiovisuais - no filme, em muitos cartazes, diversos calendários, nos tantos anúncios de jornais e revistas, na própria televisão - intensamente a figura de D. Pedro, como modelo patriótico e exemplo heróico numa ação peda gógica para educar o bom cidadão da ditadura militar. A figura de D. Pedro I foi motivo ainda de um estudo primoroso e necessário levantamento imagético de Herstal, ${ }^{11}$ com um extenso e diversificado mapeamento da iconografia existente a seu respeito, além do le vantamento de Alexandre Eulálio, arrolando documentos, iconografia e cultura material do período da independência. ${ }^{12}$ Noutra clave, a efeméride independência recebia um tratamento de pesquisa acadê mica na obra de Carlos Guilherme M ota, relizando um balanço his tórico-historiográfico da independência, 1822: Dimensões editada pela Perspectiva, que se tornou obra de referência.

Esta ampla difusão da figura de D. Pedro se devia à come moração do Sesquicentenário da Independência. ${ }^{13}$ O logotipo oficial dessa data não tinha seu uso restrito ao Estado. Pelo contrário, várias empresas portavam-no, colando-o às suas peças publicitá rias, e demonstrando assim seu amor à pátria, seu apego ao Brasil e evidenciavam que investiam no desenvolvimento do pás. Em vá rios calendários comemorativos, os meses recontam a história do Brasil desde 1500, e apresentavam os grandes homens e feitos da Independência. Usavarse bastante da ilustração, do recurso da imagem para aludir a um momento histórico do passado ou ainda (re)convertia-se o lema da Independência numa propaganda, a fim de evidenciar a história de desenvolvimento do Brasil. Nos anúncios de revista, a Petrobrás tinha por lema: Independênda em Petróleo, e o mesmo tom apaixonado e nacionalista aparecia nas propagandas da Rhodia, Pirelli, Globo, Cia. Siderúrgica Nacional, Mendes Júnior, Villares e outras mais. 
Um logotipo e ícone do período era a data de 1822 em cima, sobreposta por uma série de ondas verde-amardas sobre a data de 1972, embaixo, que ficavam unidas por essas curvas do tempo. Algo assim:

$$
1822
$$

1972

Embaixo das datas, liase:

Sesquicentenário da I ndependência. Vocêconstrá oBrasil.

Esse logotipo aparecia em profusão, criando um calendário cívico, em que as datas se justapunham, e trazia para o presente a ação tanto do passado quanto a do presente exigida de cada brasileiro. Buscavase evidenciar e reiterar nos discursos, na propaganda do Es tado e de muitas empresas a forte semelhança entre Estado e socie dade civil, tornando opaco o divórcio existente não só por meio da violência e da censura, mas também pela existência de projetos políticos que visavam a constituir uma relação identitária entre os bra sileiros e a nação. As propagandas do Estado não deixavam margem à dúvida: necessariamente se precisava ser brasileiro. Para aqueles que disso duvidassem ou propusessem outros entendimentos do sentimento cívico ou coletivo, a censura e a repressão funcionavam ve tando sua expressão e ação, assim se insistia Brasil, ameo ou dexeo. Não havia muita alternativa entre o amor e a crítica ao regime, antes pelo contrário (re)traduziase o lema Independêndia ou Morte pelo Ameo ou déxeo que exigia a adesão do brasileiro, pois seu inverso era partir para o exílio, voluntário ou não, no qual se negava qualquer possibilidade de o sujeito ser brasileiro. $O$ próprio presidente Garrastazu Médici definira os festejos como um imenso encontro dos brasileiros com o Brasil. Dessa maneira, solicitavase ao brasileiro que atuasse patrioticamente no seu presente, trabahando, estudando, no seu cotidiano; ele obrigatoriamente deveria contribuir para o contínuo desenvolvimento da nação.

A propaganda do Sesquicentenário centravase no ato fundador da nação, aquele que marca sua origem, conferelhe condição de existência Tal ato não ficava encerrado e cristalizado no passado, em 1822, antes era reativado para tornar-se um ato de cada dia e de cada um. Como condamava um hit de 1970, com a conquista da Copa do Mundo: 
90 milhões emação

PrafrenteBrasil

Salvea seleção.

Plasmavam-se os 90 milhões de brasileiros na seleção: suas tantas diferenças e todos deveriam ficar mobilizados por uma só ação em nome da nação, cujo destino era autoritariamente definido pelo governo militar. Não se celebrava o pacto entre governante e governado, antes investiarse numa espécie de vigilância mútua entre os membros desta coletividade motivada pela censura, pela violência, mas também por uma educação ćivica, escolar principalmente, pela qual cada aluno/cidadão deveria empenhar-se nas suas tarefas (da es cola, do trabalho, do esporte) e congraçar-se simbolicamente com o Brasil; daí a necessidade de festas cívicas, desfiles, paradas, apresentações militares e celebrações públicas. Aí, o Sesquicentenário agigantava-se Referia-se à própria história da nação e sua fundação, trazendo-as para o presente Tal celebração pedia dos envolvidos uma presença na cena pública para assistir aos cortejos dos restos mortais de D. Pedro, para as paradas militares, para cantar o hino nacional na escola, na fábrica, ouvi-lo em posição ereta e solene. Ainda é impressionante a fotografia na revista Mandhete de setembro de 1972, na qual se vê toda uma população enfileirada, nas calçadas, com bandeirinhas sendo agitadas pelas crianças, os homens, civis, de capace tes verde-amardos e o tanque militar rasgando a rua levando o corpo do herói.

Segundo as revistas da época, às 18:30 horas do dia 7 de se tembro, Médici convidava os espectadores na TV a voltar o pensamento para os preaursores que, nas manifetações nativistas, nas lutas externas e fronteiriças nos movimentos preaursores e nas guerras de Independência, ensinaram às gerações sucessivas que a soberania de uma nação não se outorga, não se recebe de presente, antes se conquista, se preserva e se amplia, com o trabalho, a inteligêndia, o idealismo, a re núncia e, se preciso, o sangue de homens como nós

Datam de 1972 dois curtos documentários, cinejornais ${ }^{14} \mathrm{em}$ preto e branco, que narravam a chegada e a recepção do corpo de D. Pedro, e seu translado pelo Brasil, numa espécie de procissão e via cucis A trajetória do corpo pelo país vinha acompanhada de uma série de metáforas que o tornam uma relíquia que cumpre uma pere grinação, termos de cunho religioso, que o qualificam e dotam de uma aura mítica Nesse périplo, ressoava o tema da integração nacio- 
nal, tão caro aos militares, como se via nas obras viárias (Transamazônica, por exemplo) e nos sistemas de comunicação (a expansão da televisão, por exemplo). Pois, o corpo de D. Pedro cumpria simbolicamente tal integração e reforçava com sua presença a importância da empreitada militar e do governo de unir todo o pás.

Muitas vezes, a passagem do corpo por uma cidade vinha acompanhada de um festejo local: campeonatos esportivos, aniversário da cidade, desfile, missa. Unia-se uma data, um festejo, um motivo municipal à recepção do corpo, mobilizando a população local.

Noticiava-se num tom enfático que o corpo percorria o país de norte a sul, integrando-o como seu governo fizera em 1822. Nesse percurso, destacava-se sua chegada a São Paulo. Nas solenidades em São Paulo prepondera a presença masculina, de civis e militares, que com seus corpos rijos, em ternos, roupas formais, asseadas, causam uma impressão de sociedade coesa e de autoridade presente.

Esses dois cinedocumentários recobrem dois eventos, o 22 de abril e o 7 de setembro. Ambos tratam da chegada do corpo do he rói. Exibem as solenidades como se a sua câmera fosse um ol ho neutro, privilegiado porque a tudo assiste, mas não se envolve, apenas retrata. Esse tom naturalista parece dizer que o evento aconteceu dessa maneira, sem abordar ou sugerir o esforço de operacionalização que um festejo desse porte exige D. Pedro volta ao I piranga mostra uma festa cívica em 26 de agosto, preparando o espírito para a che gada do féretro. Em 26 de agosto, no Pacaembu, foram reunidos 6 mil estudantes, 300 num espetáculo de ginástica rítmica, configurando com seus corpos e gestos a figura de $D$. Pedro montado a ca valo e os dizeres: Independência ou Morte No dia 7 de setembro, desfilaram 18 mil homens, com Médici comandando o espetáculo como chefe supremo das Forças Armadas, e, no Ipiranga, fez-se um show de luzes sobre as idades do Brasil que, segundo estimativas da época, foi assistido por 100 mil pessoas.

Em D. Pedro, 150 anos depois, há ao final uma seqüência que intercala a coleção de pintura histórica do Museu do I piranga a res peito da Independência - como se evocasse e mostrasse o passado com o cortejo, a solenidade, o próprio ato da celebração no presente (1972). Esses cortes cinematográficos enaltecem a atuação de D. Pedro em 1822 e seu reencontro com o I piranga, seu grande feito, em 1972. Assim, reapresentar, nessa seqüência, o quadro de Pedro Américo duplica, torna presente e atualiza o grito do Ipiranga, con- 
siderado o gesto que funda a nação. A última fala desse documentário, na locução inflamada de Ruben de Falco, prodama: Independência ou Mortel Como se emprestasse sua voz ao grito do I piranga e, ali, e imagem e som atualizam a ação do passado, tentam trazer a carga dramática do passado para o presente, encenando-o.

Esses cinejornais levavam para a sala de cinema o cortejo da rua, a celebração militar e o que se chamava de cívica, e, na sua re petição a cada sessão, reiterava o feito. De certa maneira, complementavam o filme Independência ou Morte, de Carlos Coimbra, que num tratamento naturalista da linguagem cinematográfica - decupagem clássica, unidade espaço-temporal, cuidadosa recuperação histórica do período expressa nos cenários e no figurino - tentava recontar a história da independência num filme histórico, então incentivado pelo ministro da Educação, que chegara a sugerir aos cineastas te mas históricos que pudessem informar a produção cinematográfica: a FEB, Borba Gato, Marechal Rondon, Duque de Caxias, entre outros. $^{15}$

Esse filme, depois reprisado pelas emissoras de TV, não era uma encomenda do Estado, embora fosse bem acolhido por ele $\mathrm{O}$ próprio presidente Médici enviou um telegrama saudando o filme em 1972, acolhendo-o.

O filme prima pela montagem, pela presença de atores que freqüentavam mais a TV, sobretudo as novelas, sendo, salvo engano, das primeiras vezes que isso acontecia com eficácia, como um recurso para chamar a assistência O filme congelava o evento-independência, tão celebrado no espaço público e na mídia, ao inseri-lo numa dada narrativa imagética que repunha a versão histórica "oficial" desse processo presente nos livros didáticos. O filme funcionou em certa medida como a crônica histórica desse fato e o espectador, quase didaticamente, aprendia a história do pás, daquele herói, no filme. Nessa direção, o ápice da sua narrativa coincide com a proclamação do grito do I piranga que encena o quadro de Pedro Américo. Os ca valos, a guarda e D. Pedro ajeitam-se e posicionam-se de modo que se duplicou o quadro, inclusive com aquela figura cabocla na late ral, que passa e assiste ao fato. Ali, o fato histórico elaborado pela pintura histórica convertia-se no acontecimento histórico, tal e qual, e a câmera flagravaro de vários ângulos.

Em contraponto, é interessante retomar Os Inconfidentes filme de Joaquim Pedro de Andrade, de 1974. Ele recupera a Inconfi- 
dência Mineira por intermédio da documentação dos Autos de De vassa da Inconfidência Mineira, pela poesia dos próprios inconfidentes e pelo Cancionero da Inconfidênda, de Cećlia Meirelles. Permite que os personagens, os inconfidentes, falem os textos que se encontram nesses escritos. Assim, mistura planos históricos, reais, oníricos, poéticos, recusando-se a fazer uma versão naturalista do acontecido. No enredo, expunha a dramática relação dos intelectuais com o Estado metropolitano e o horror de estar entregue à re pressão do Estado português Viase uma espécie de metáfora da condição de liberdade cerceada no presente e o horror da violência da prisão política, também vividas no passado pelos protagonistas des sa revolta Ecoa, na prisão dos inconfidentes, o medo da tortura, a delação, a violência perpetrada pela ditadura. No final do filme, insistese nesse jogo entre o tempo passado e o do presente, quando se cumpre a sentença de Tiradentes. Ele é enforcado, seu corpo re partido, exposto em praça pública. Em seguida, aparece uma cena do tempo presente, um cinejornal tratando da comemoração do 21 de abril em Ouro Preto. Aí, Tiradentes era motivo de solenidades, discursos oficiais, desfiles. Tiradentes transforma-se no herói da na ção, ao invés de D. Pedro, seja pela sua capacidade de suscitar comemorações ć́vicas no presente, seja pela violência sofrida em vida. O herói, percebia Joaquim Pedro de Andrade, consistia numa figura que tem o corpo esquartejado. Ele assim significava a nação. De novo, a praça pública reaparecia no filme evidenciando sua polis semia, servia, na sua perspectiva, tanto para imolar alguém que lutara pela liberdade quanto para solenidades oficiais que tentavam expressar a coesão social.

Notas

1. Especialmente capítulos 29 e 30. Disponível em: «ttp://www.redeglobo.com.br/ oquintodosinfernos>.

2. VARNHAGEN, F.A. História geral do Brasil. Rio de Janeiro: Laemmert, 1854-57.

3. A ESTATUA Eqüestre do fundador do Brasil. O Guanabara, Rio de Janeiro, n. 2, p. 289, 1851.

4. JANCSÓ, I. A construção dos estados nacionais na América latina: apontamentos para o estudo do Império como projeto. In: SzMreCSÁnyı, T.; AmARAL LAPA, J.R. História econômica da independênia e do império. São Paulo: Hucitec, 1996.

5. PÁTRIA do cidadão: a concepção de pátria/nação em Frei Caneca. Revista Brasileira de História, São Paulo, v. 18, n. 36, 1998. 
6. É possível recuperar esse debate nos números desses jornais publicados em outubro de 1822, que se dedicaram a descrever a aclamação e a forma pela qual a explicavam.

7. O JOGO duro do 2 julho: o partido negro na independência da Bahia. In: ReIS, J.J.; SILVA, E. Negociação e conflito: a resistência negra no Brasil escravista. São Paulo: Cia das Letras, 1988.

8. Ata da Aclamação do Sr. D. Pedro Imperador Constitucional do Brasil e seu Perpétuo Defensor. In: CONSTITUIÇÕES do Brasil. Rio de Janeiro: Aurora [s.d.]. v. 1, p. 23.

9. MELLO MORAES, A.J. Hisớria do Brasil Réno e do Brasil Império. São Paulo: Edusp; Belo Horizonte: Itatiaia, 1979.

10. BLUTEAU, R. Vocabulário portuguez e latino. Coimbra: Collegio das Artes, 171224; SILVA, A.M., Diccionario da lingua portuguesa ; recompilado dos vocabulos impres sos até agora, e nesta segunda edição novamente emendado, e muito acrescentado por Antonio de Moraes Silva. Lisboa: Typ. Lacerdina, 1813.

11. HERSTAL, S. Dom Pedro. São Paulo: MEC; Lisboa: Ministério dos Negócios Estrangeiros, 1972.

12. MEMORIA da Independência: 1808-1825. Rio de Janeiro: IHGB/MEC, 1972.

13. É bom observar que a ditadura costumava celebrar seu aniversário, tornado festa nacional, e, em 1970, a conquista do tricampeonato de futebol e a Semana da Pátria tinham motivo de festa nacional. Logo, o Sesquicentenário inserese e destaca-se num tempo festivo desde o início da década.

14. Tratase de D. Pedro volta ao I piranga, sob direção de Rubens Rodrigues dos Santos, e D. Pedro, 150 anos depois de Primo Carbonari, ambos de 1972. Consultei as cópias existentes no MIS-SP. Agradeço a Eduardo Murguel a indicação.

15. BERNARDET, J.-C.; RAMOS, A.F. Cinema e história do Brasil. São Paulo: Contexto; EDUSP, 1988. 